\title{
WOMEN, LAND AND EMPOWERMENT IN RWANDA
}

\begin{abstract}
Rwanda has recently registered all legal owners of land and has required spouses to be registered as co-owners of joint property; this is aimed at contributing to the empowerment of women, among many other things. A 2015 survey explored the impact of law and official practice on women's empowerment - whether they knew their rights and whether they could claim them. The conclusion is that there has indeed been some impact. The problems of women's subordination remain, however, given patriarchal attitudes, unequally shared decision-making, and a tension between Rwanda's espousal of the Rule of Law on the one hand and the principle of dialogue and consensus on the other. Moreover, the position of a substantial proportion of women, in unregistered domestic partnerships, has not changed.
\end{abstract}

\section{INTRODUCTION}

The vast majority of Rwandan households own land (Abbott and Mugisha 2015; Niyonsaba et al 2013). Land is the main source of subsistence for a majority of the population and the only wealth of most families. Rwanda's declared policy is to eliminate inequalities between men and women, and some of its tools for doing so are the inheritance laws and the land laws, coupled with a regularisation of the system of land tenure to include rights for married women. Land Tenure Regularisation (LTR) has involved the systematic identification of occupiers of all land in Rwanda to determine legitimate occupancy and issue long-term tradable leaseholds. Rwanda is the only country in Sub-Saharan Africa that has succeeded in formalising and documenting individual land tenure on such a comprehensive scale (UNHabitat et al 2012). Rights for married women are enforced as part of the registration. This article sets out findings from a survey carried out in 2015 - the first representative survey in Rwanda to tackle some of these topics - on respondents' experience of LTR, their knowledge of the laws and their ability in practice to claim and be accorded the rights which the laws and LTR are supposed to afford them.

The research described in this article was carried out before the 2016 Law Governing Matrimonial Regimes, Donations and Inheritance was passed and gazetted in Rwanda, so the legal position regarding inheritance is now a little different in its detail from the situation to which the survey respondents were reacting, which was based on the 1999 Inheritance Law and the 2013 Land Law. The changes do not make any substantial difference to the arguments of the article, however (see Note at end of text). 


\section{BACKGROUND AND CONTEXT}

Following the devastating effects of the 1994 Genocide against the Tutsi, Rwanda has become a relatively stable and peaceful country with one of the most effective governments in Africa (Booth and Golooba-Mutebi 2011, Collier 2010). The country's ambitious social programmes makes it dangerously aid-dependent, and the poor balance of imports and exports renders it vulnerable (Abbott and Sapsford 2016), but the economy is growing and poverty is recorded as declining (though the method of measurement has changed over the years and the figures are therefore not entirely to be trusted). There is legislation for gender equality, and Rwanda is famous for the proportion of women in its Parliament, though this is slow to be duplicated in industry or even in government (Burnet 2011).

Land and its produce remain crucial to Rwanda's economy and the survival of its people. Only $6 \%$ of agricultural production by value is exported, but this accounts for over $40 \%$ of the value of exports (Ministry of Finance and Economic Planning 2014, NISR 2015b).

Agriculture was listed as the main occupation of $60 \%$ of men and $80 \%$ of women in 2013/14 (NISR 2015a). There is huge pressure on land: Rwanda is one of the most densely populated countries in the world, and the average area cultivated by a rural household is 0.6 ha, despite FAO estimates that at least 0.9 ha of land is needed for a household to feed itself (NISR, 2012c); three quarters of agricultural plots are judged to be too small to support a household by themselves (Abbott and Mugisha 2015).

The 2003 Constitution mandates gender equality, gender is mainstreamed in all government policies, gender quotas ensure the representation of women at a national level in government and gender-responsive budgeting is practiced (Abbott et al 2015). Laws governing land (Law No 08/2005 and its successor, Law No. 43/2013) and inheritance (Law No 22/1999) give women the right to own land in their own right, girls have the same right to inherit as boys, and married women in legal (registered) marriages where community of property has been chosen as the 'marital regime' (the vast majority) are co-owners of their joint property and have the same legal rights in principle as their husbands to participate in controlling it and disposing of it. The underlying question which this article seeks to address is the impact of the laws and LTR - whether women know their rights and whether they are able to obtain them through the dispute-regulation mechanisms. Our model of empowerment comprises the existence of legal rights, women's awareness of them, awareness of them by others (especially those involved in dispute-resolution) and the absence of barriers to their being asserted successfully.

\section{Women and land}

LTR was rolled out across Rwanda in 2012-14, and land titling is now virtually complete, bar possibly a small number of disputes about ownership. All owners and interested parties, including legitimate children and any illegitimate children recognised by the husband. have to 
be named on the registration document as having an interest in the land; women legally married (in civil ceremony involving registration of the marriage) who have opted for community of property also appear as joint owners and have the right to be consulted about land sale and management.

Gender equality is a human right in itself (see e.g. United Nations 1979), but women's empowerment is also an element of 'smart development' (World Bank 2012). Promoting gender equality and empowering women gives nations access to the other half of their human capital. Economically empowered women drive development (Elborgh-Woytek et al 2013) they produce an increase in GDP at national level, and any money they earn tends to improve the wellbeing of children and men (Burgess 2007).

Women's right to own land is complicated by the law on inheritance. Before the 1999 Law, women had no ownership of the household's property and did not inherit it, though they might manage it in the interests of dependent children. The inheritance law of 1999 created a category of 'community of property' which meant that women and men had joint ownership of the property, including what was brought to the marriage and anything acquired afterwards as joint property. On the death of one partner, half the joint property reverted to the sole ownership of the survivor, and the remainder passed to the deceased's children (in equal shares (unlike umunami - gift of land to children on coming of age - which at the time of the survey could be given in unequal allocations), or to other relatives of the deceased spouse if there were no children. These rights of inheritance are restricted, however, to the family members of a registered civil marriage plus, from the man's share, illegitimate children recognised by him during his lifetime. (Women's illegitimate children are taken automatically as having been recognised by their mother, because the fact that she gave birth to them is known.) The law provides no protection to women or men living in consensual unions (i.e. not state-registered), which can leave them and their children especially vulnerable; on being widowed or abandoned a woman can be left without means of support. However, there is also nothing in law that prevents partners who are living in consensual unions from registering land jointly, and this has occurred under LTR, as we shall see.

Ownership of land does not necessarily increase women's economic empowerment, however; they need also to share control over the land and its uses. Even when married women know their rights and have their names on the land title they may have little say in how land is used or how the income from the sale of surplus or cash crops is spent (Abbott and Malunda 2015; Abbott et al 2012). Provisions in the law, especially the 1999 Inheritance Law, reinforce traditional values that see women as dependent on and inferior to men (Abbott and Alinda 2012; Poplavarapu 2011). This is not the situation of legal pluralism which prevails in some African countries, with 'tribal' laws working in parallel with statute law under rules as to which shall prevail. Before statute law in Rwanda the common understanding was that land belonged ultimately to families and was inherited in the male line, so a wife (from outside the family) was unable to own land at all, but statute law abolished the old legal bases. The 2006 Land Law and its successor, the Law of 2013, make all land ultimately the property of Government, to be managed for the good of Rwanda. Smallholder farmers have a 99-year lease, and there does not seem to be any concerted resistance to this principle. (The state has 
the power to take away land which is not being properly used and reassign it, however, and there are the usual provisions found in most countries for requisition of land needed for public projects; unremarkably, these are less popular.)

\section{Land disputes}

The importance of land ownership is demonstrated by the number of land disputes. It has been difficult in the past to get quantitative data on land disputes, but one recent survey found that just over one landowner in 10 (13\% of women and $12 \%$ of men) was engaged in a dispute at the time of the survey (USAID Land Project 2014b). Disputes were as likely to be with neighbours about boundaries as with family about inheritance (31\% of all disputes in each case), with the other noticeable category being disputes with government (18\%). It has also been difficult to determine the extent to which disputes are being resolved to the satisfaction of claimants.

Where the problem comes in land practice is that Rwanda has opted formally, in its Constitution, for 'consensus' rather than 'debate' in its governance. At national level this means that decisions are generally not taken which risk dividing the population; they are more likely to be put to one side for further dialogue than forced through while leaving any significant group dissatisfied. At the level of individuals and households its corollary is that civil disputes should be sorted out without formal recourse to the law if this is possible, by discussion leading to an agreed solution. This sets up a conflict of principle between the concept of the rule of law as guardian of individual rights and the need for consensus, or at least agreed compromise, to preserve unity and avoid factional grievance. 'Mediation committees' (abunzi) have the duty of this mediation, and the law makes their use prerequisite before taking cases to the courts (Organic Law No. 02/2015). Most land disputes are dealt with first at an even lower level of dialogue, by the family meeting or local leaders, with only a minority of cases being dealt with even by the abunzi, let alone the courts (authors' analysis of Senate Survey dataset - see also Veldman and Lankhorst 2011). The research literature suggests that knowledge of the rights and obligations contained in the land and inheritance laws is patchy among people in general, local leaders and even the Abunzi (Abbott and Alinda 2012; Abbott and Rwica 2014; Mutisi 2012; USAID Land Project 2014a). The Laws governing the abunzi, both the 2010 Law and its revision in 2015, require that the solutions they propose shall be within the written law and shall draw on customary practice only where this is not in conflict with the law. However, the pressure in mediation is to bring the parties to agreement and the oath the abunzi swear requires them to 'seek first to conciliate the two parties' (Organic Law No. 24/2010), which may mean each party giving up something to which the law entitles them (Mutisi 2012). The decisions of the Mediation Committee are not binding - they may be appealed in the primary courts - but few can afford to take their disputes there (Ndangiza et al 2013). Women may therefore settle for a mediated outcome that they know does not meet their full legal entitlement (Abbott and Alinda 2012; Abbott and Rwica 2014). 
LTR aimed to ensure that women married under community of property and the widows from such unions have been recorded as co-owners on lease certificates. Listing all those with an interest in the land also means that the inheritance rights of daughters as well as sons are protected. Widows and female orphans have been able to claim back land to which they have a legal right which was previously grabbed by their relatives (Uwayezu and Mugiraneza 2011). LTR and its initial wide round of 'sensitisation meetings' increased women's understanding of their land rights, with virtually all women knowing that they had the same basic right to inherit land as men (Santos et al 2012, Niyonsaba et al 2013). However, later research (Santos et al 2014) suggests that there is still considerable misunderstanding of the detail of women's rights and that local leaders, volunteers and paralegals do not have a comprehensive and accurate understanding even after training (Abbott and Rwica 2014).

\section{METHODS}

The aim of this research was to gather nationally representative data through an intervieweradministered survey on the impact of law and official practice on Rwandan women's empowerment - whether they knew their rights and whether they could claim them. For greater detail of the methods, see Abbott and Mugisha (2015).

The survey was targeted at all non-institutionalised adults (18 or older) in Rwanda. We used a multi-stage probability sample:

1. The current administrative structure of the country subdivides the population of Rwanda into 30 districts; 15 of the districts were randomly selected.

2. A sample of 60 villages was selected - four villages in each of the selected districts, with probability of selection proportional to the number of households in the village. (A 'village' is the smallest administrative unit in Rwanda. It is not necessarily a centralised settlement, as in rural areas there is a tendency to build the house on a plot of land also used for crops.)

3. In each sampled village, a 10\% random sample of households was selected using lists held by the village leaders, updated by the survey team as necessary, and all the adults normally resident in these households were targeted for interview. (In other words, the selection excluded people who were present only temporarily during the survey period, as visitors, but included everyone who would count the household as their residence even if they were temporarily away at the time of the survey (e.g. on a visit or at boarding school.)

Applying the usual formula yields a minimum sample size of 423 households, to be $95 \%$ confident of household results being accurate within $\pm 5 \%$. The procedures listed above yielded a sample of 480 households, all of which agreed to participate in the survey. The total number of individuals identified for interview was 1,089, and just over $78 \%$ of then were contacted and interviewed. The non-contact/non-response rate is low by international standards but higher than is usual in Rwanda, and there may be under-representation of some groups, discussed further below. 
The questionnaire was based on the one used for the 2013 survey carried out by Niyonsaba et al. Questions were retained that had been used to measure the impact of LTR in the previous study; others were added that would provide information on land ownership, the LTR process and dispute resolution. We added detailed questions to measure women's (and men's) understanding of land and inheritance rights, based on the laws of the time. The questionnaire was drafted in English and translated into Kinyarwanda and the translation checked for accuracy. It was then piloted and amended in the light of the findings and a further check made of the accuracy of the Kinyarwanda version.

Interview fieldwork was carried out between $30^{\text {th }}$ March and $10^{\text {th }}$ April, 2015. At each sampled household the interview team listed all the members aged 18 or over and normally resident; this formed the list to be interviewed. Respondents were interviewed face to face, away from other family members, and informed consent was obtained in all cases. Time constraints on carrying out the survey meant that it was not possible to do the three call-backs that are generally made to increase the response rate, and the second week of fieldwork coincided with Genocide Memorial Week, which reduced the response rate in some households. Those who have non-farm employment away from the home and those in fulltime education may particularly have been under-represented.

Analysis was carried out using SPSS. Scales and composite measures were computed as follows:

- a composite measure of 'perception that LTR reduces land conflicts', by combining the inter- and intra-household items into a single variable;

- a measure of 'understanding of basic land rights', based on the number of correct answers given to questions on who can own, who can inherit, who can rent and who can purchase land;

- a measure of 'working knowledge of land rights' based on the number of correct answers given to all 12 questions measuring knowledge of land rights;

Steps were taken to ensure the ethics and quality of the research: training of research assistants, eliciting informed consent, a guarantee of and a reminder that respondents had the right to withdraw at any time during the interview. Team leaders were responsible for ensuring that the members of their team actually contacted households, carried out interviews and correctly completed the questionnaires, through call-backs to a random $10 \%$. Once the data had been entered, respondents' personal details were stored in a different secure place from the main questionnaires. After the analysis was completed all records of personal details were destroyed.

\section{FINDINGS}

Three quarters of adults living together as a couple had married in a civil ceremony (78\% men, $76 \%$ women) - see Figure 1. Of these the vast majority had opted for community of property $-90 \%$ of men and $87 \%$ of women. 
Figure 1: Marital Status by Gender, \%

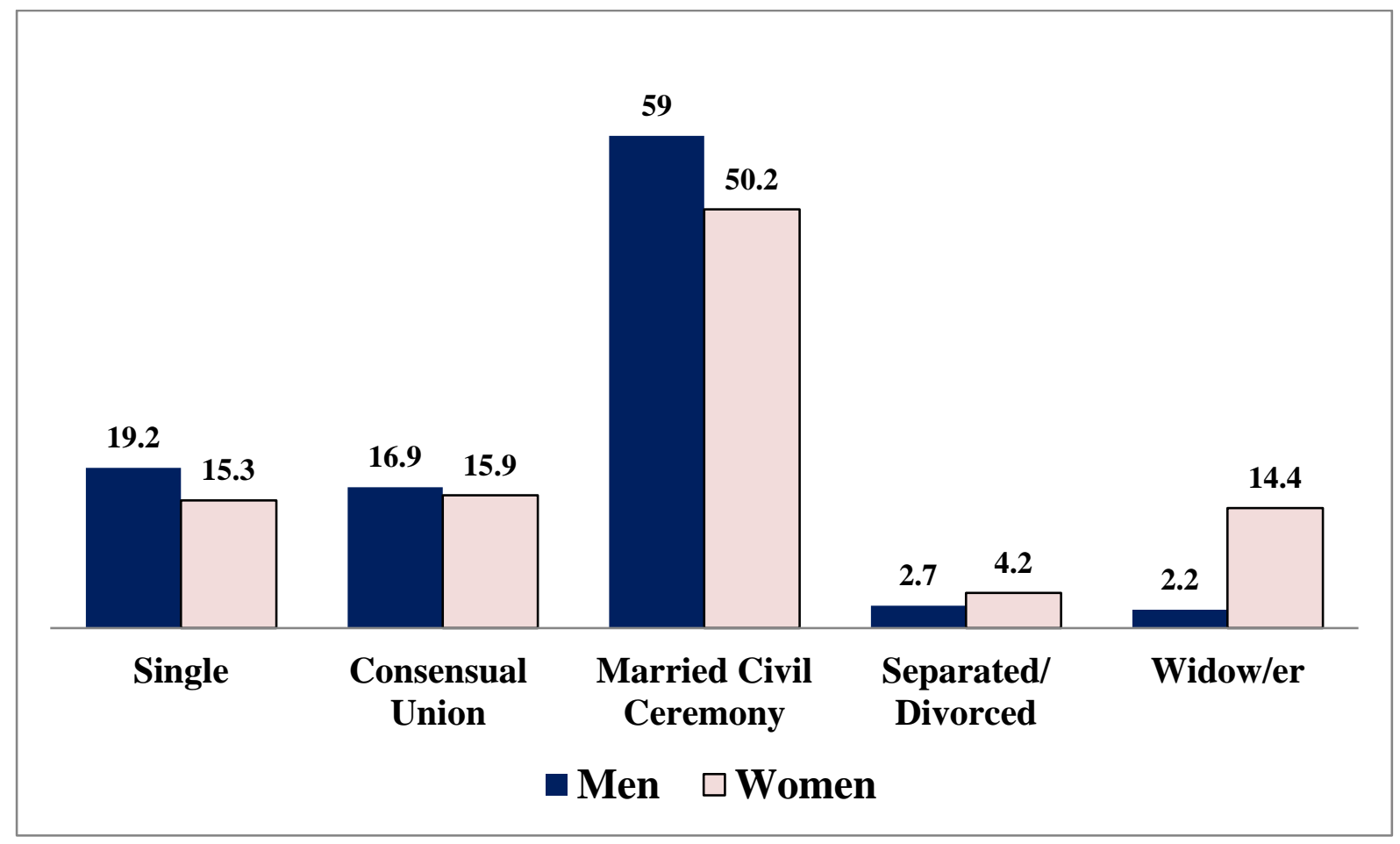

The vast majority of adults were economically active - $96 \%$ of men and $89 \%$ of women. Three quarters were engaged in subsistence farming and a further $37 \%$ in farm labouring. Women were more likely to be engaged in farming than men and men were more likely to engage in non-farm livelihood activities (Figure 2). In terms of main livelihood activity, women were much more likely to be engaged in agriculture than men, while men were noticeably more likely to be engaged in non-farm activities (Figure 3 ) - though it is interesting that a majority of the women who would class themselves as dependent workers are in fact co-owners of the farm or plot.

Figure 2: Employment in Last Year, by Gender, \%

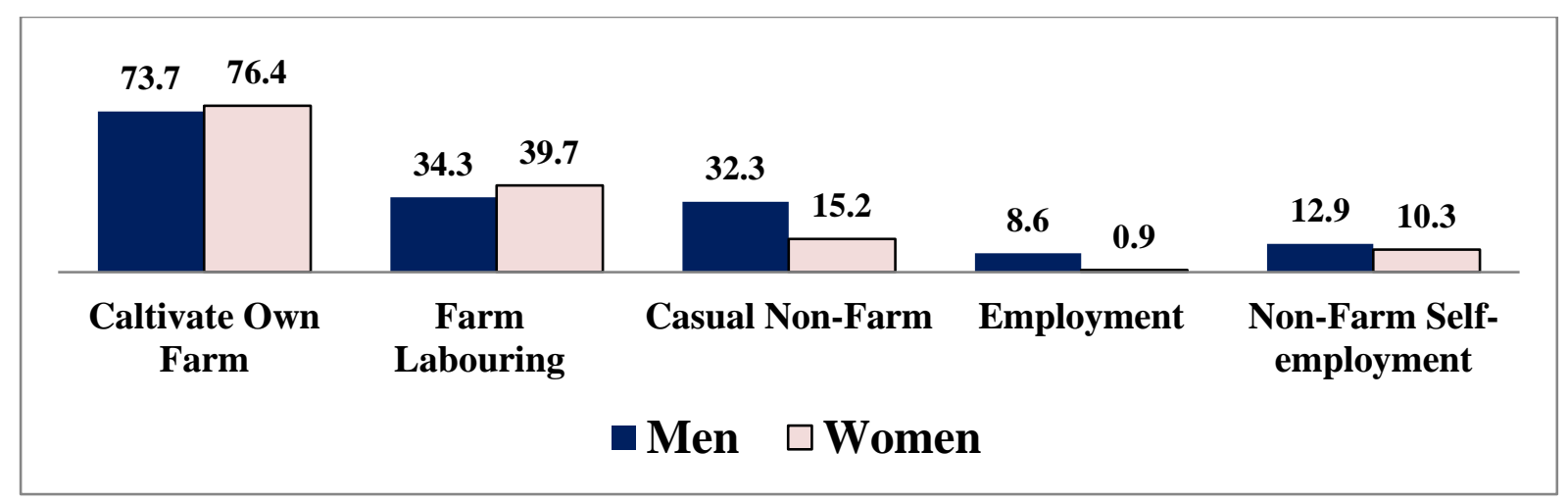

Note: totals add up to more than $100 \%$ as some people have engaged in more than one livelihood activity 
Figure 3: Main Employment, by Gender, \%

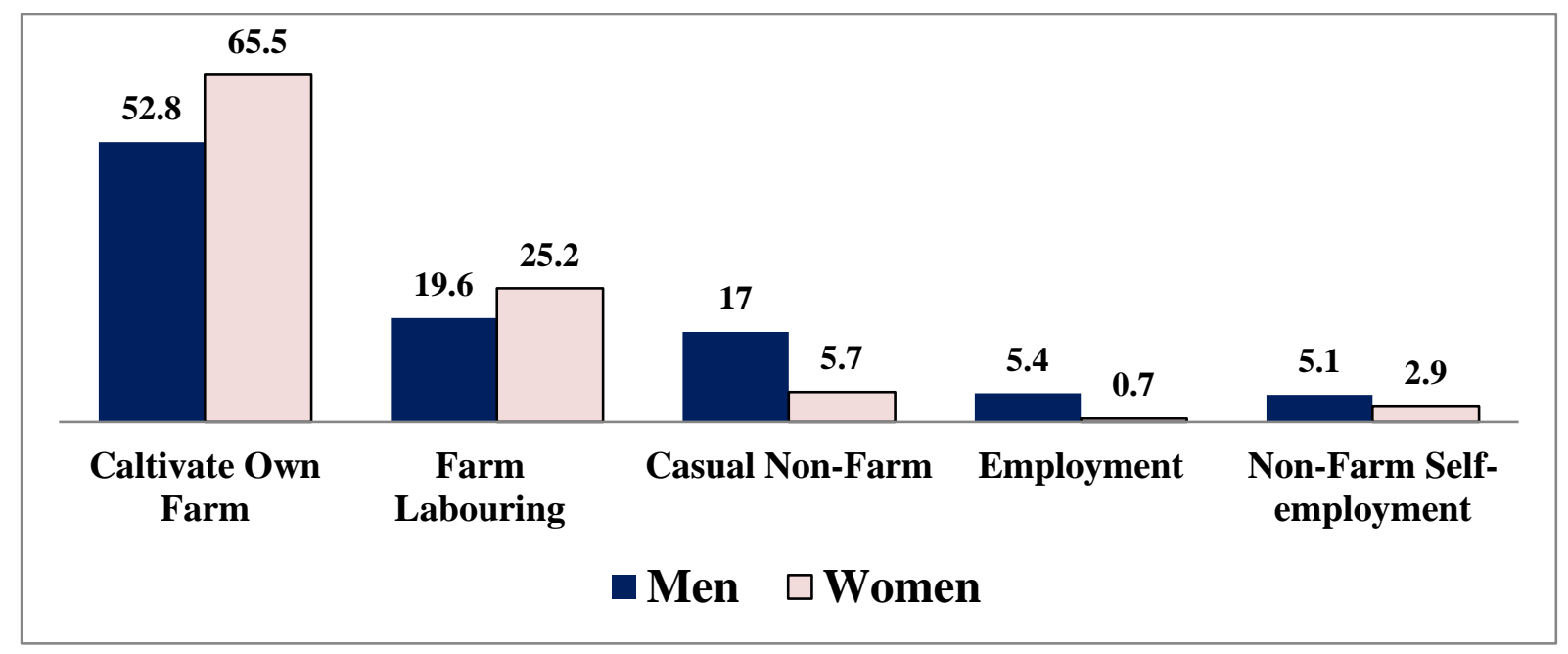

\section{Land ownership and registration}

Only $9 \%$ of households did not have access to land; $77 \%$ of adults were landowners $-78 \%$ of men and $75 \%$ of women. The most frequent way in which land is obtained is through umunami (gift of land on reaching majority), with men more likely to have obtained land in this way than women (Figure 4). The second is by purchase. Women are twice as likely as men to have become owners of land through marriage; until now it has not been given consideration in the research because in practice it is mostly men who have the land on marriage, although women have inherited equally with brothers since 2005 . The reason for this is that most land is obtained through gift from parents (umunami) and not on death, and under the 1999 Inheritance law parents could (and generally did) give sons much larger gifts of land than daughters. However, under the 2016 law parents will have to give the same to all children (see Endnote), and land brought into the community of property by the wife may become a larger issue in the future.

Figure 4: How Obtained Land, by Gender, \%

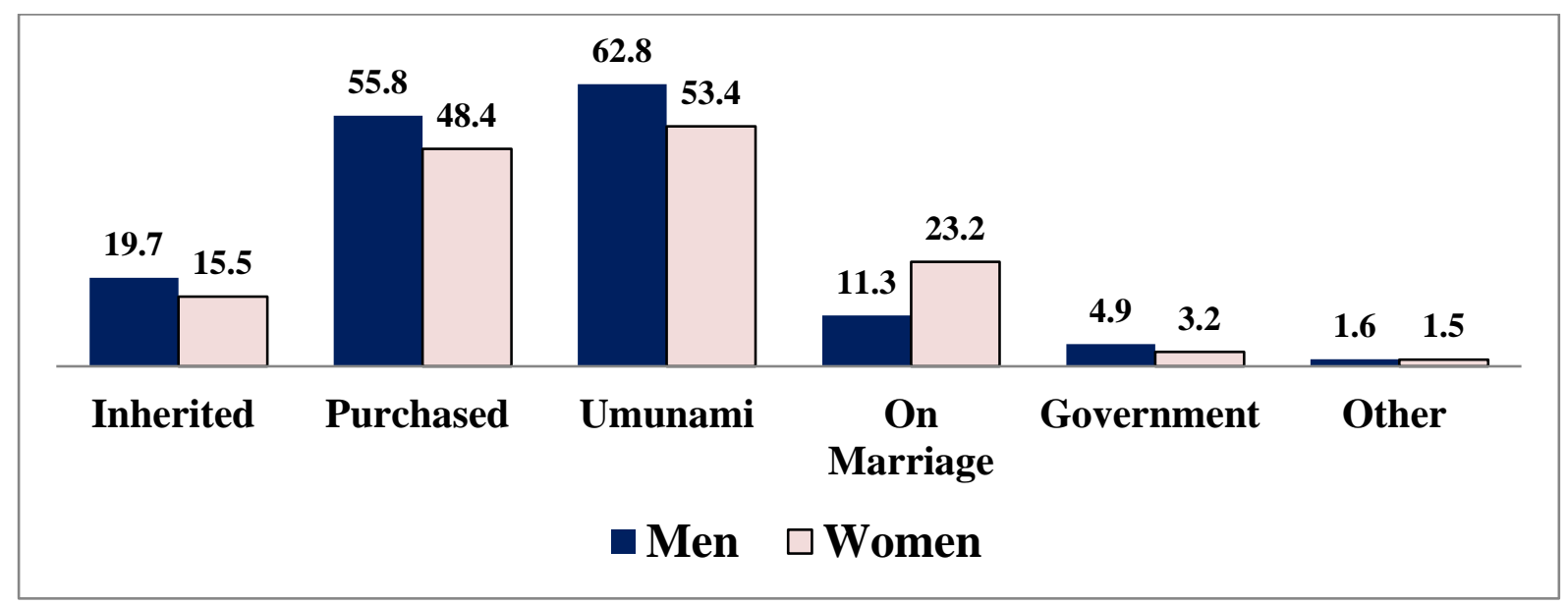

Note: totals add up to more than $100 \%$ as some respondents obtained land from more than one source 
The most common form of land registration was in joint name; $60 \%$ of all landowners' land was registered jointly. Three quarters of landowners who elected for community of property on marriage registered land jointly, but also $48.3 \%$ of those living in a consensual union. In other words, a quarter of adult landholders married under community of property had not jointly registered their land, despite the legal requirement which the Land Registry is required to ensure, and nearly half of those living in a consensual union had done so.

The survey looked at knowledge of the inheritance and land laws. Ninety-three per cent of both men and women had at least a basic knowledge of women's rights - that is, that women can own, inherit, purchase and rent land on the same basis as men. There are no significant differences by household's poverty status, education or ownership of land. People living in Kigali (the capital city) were a little more likely to do so than those in other towns or in rural areas, irrespective of gender. There was no detectable correlation with marital status.

However, the men and women themselves were not so sure that they did have a basic understanding of their land rights, and women were less certain than men: only $81 \%$ of men and only $74 \%$ of women said that they thought they know their rights correctly. Only $9 \%$ of women and $13 \%$ of men had received any instruction in land rights. The main sources of information for both men and women were community meetings, the radio and the LTR process itself (Figure 5).

Figure 5: Main sources of Information on Land Rights, \% Men and Women

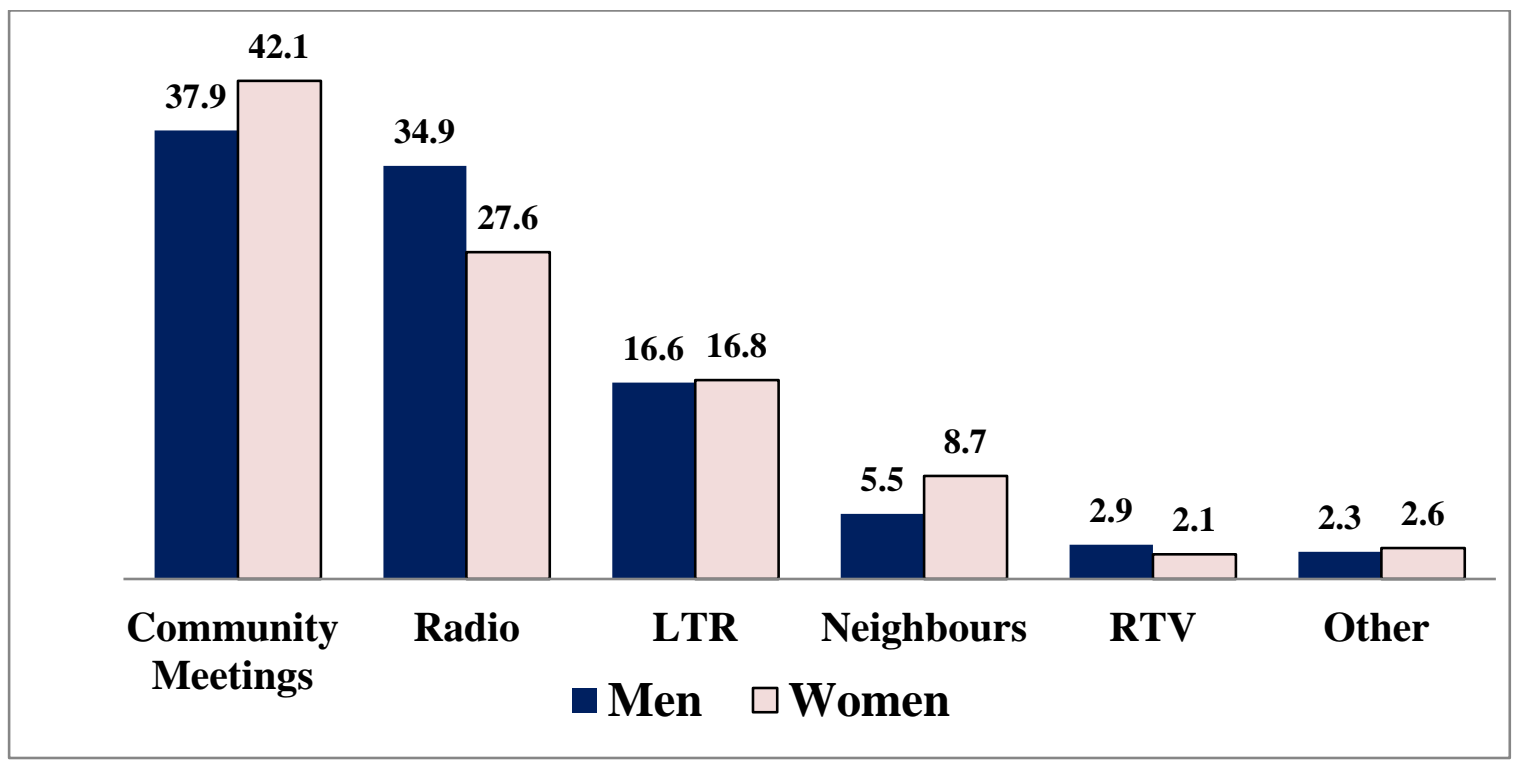

Looking in more detail at women's and men's understanding of the land laws, however, it is clear that their specific knowledge is often not fully adequate (Figure 6). This is perhaps not surprising, given the high reliance on community meetings for gaining information about the laws and on radio programmes that are unlikely to give comprehensive information. It is important, however, because intra-family disputes most frequently involve more complex issues than just the basic rights of inheritance. 
Figure 6: Percentage of Men and Women that Answered More Detailed Land Rights Questions Correctly

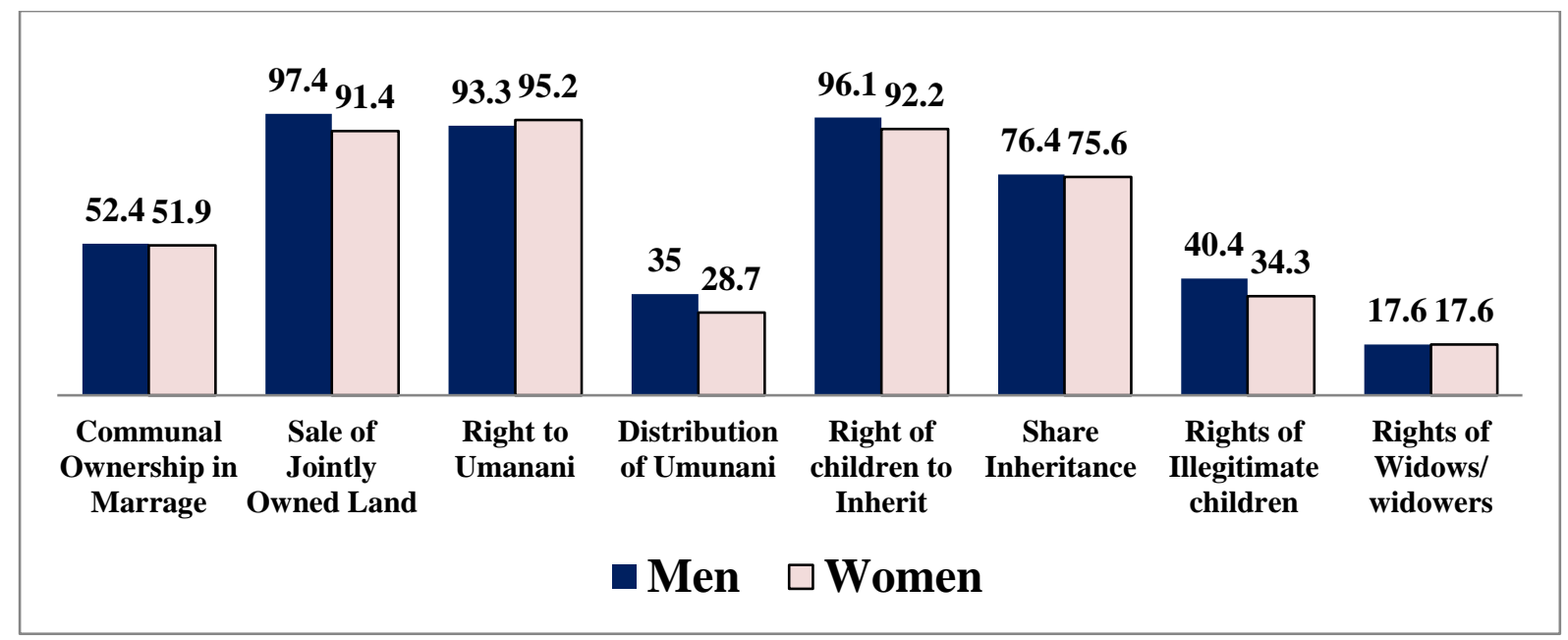

Over $90 \%$ of both men and women knew that:

- if they gave I to any of their children they had to give it to all of them,

- daughters as well as sons inherit land from their parents, and, perhaps more unexpectedly,

- if a husband and wife jointly own land then they both have to agree to the sale.

- However, only three quarters of either men or women knew that all their children should inherit an equal share of land

- and only $40 \%$ of men and $34 \%$ of women knew that illegitimate children do not have the same automatic rights to inheritance and umunami as legitimate ones.

- Only just over a third of men and $29 \%$ of women knew children did not necessarily have to get the same amount of umunami, by the law of the time.

Gender differences in knowledge were few and slight. While virtually everyone was aware that partners become co-owners of land, only 52 per knew that this was mandated by law only when a couple had married under community of property; around $30 \%$ thought it was the case for any couple that married in a civil ceremony, and around $15 \%$ that all couples shared land in common, whatever their form of marriage. Only $18 \%$ understood the land rights of widows/widowers: that when formally married under community of property the surviving partner has ownership of $50 \%$ of the land. Twenty-two per cent of men and $27 \%$ of women thought that a surviving partner inherited the property whether they had had a civil or traditional marriage or had merely lived together, and $55 \%$ of men and $50 \%$ of women thought that the surviving partner inherited provided they had been married in a civil ceremony, whether or not they had chosen community of property.

\section{Ability to Exercise Land Rights and Dispute Resolution}

Over $90 \%$ of adults thought that LTR made it easier for people to assert their land rights and more likely that land disputes would be resolved. There were no significant differences by 
gender, poverty or education but those that owned their own land were significantly more likely to think that LTR had strengthened their ability, although the difference was not large 95\% compared to 87\% (Cramer's V: p<0.001).

Seventeen per cent of landowners have been involved in a land dispute, with little difference between men and women, and $32 \%$ of disputes had taken place in the last two years; despite the perception that land disputes are declining this does not seem to be the case. However, men are more likely to have been involved in a recent case than women; $37 \%$ of the disputes reported by men were in the last two years compared with $26 \%$ of those reported by women. Women were more likely than men to have been involved in disputes with their family $68 \%$ compared to $58 \%$ - and to have been involved in disputes about inheritance; $40 \%$ of disputes reported by women concerned inheritance compared to $20 \%$ reported by men. (Not all of the claims will have been justified, of course; for example, women whose partners died before the 1999 Law was gazetted do not fall within the Law,) Men are much more likely to have been involved in disputes with neighbours about boundaries - $28 \%$ compared to $11 \%$ of women (Figure 7).

Figure 7: Causes of Disputes Reported by Women and Men, \%

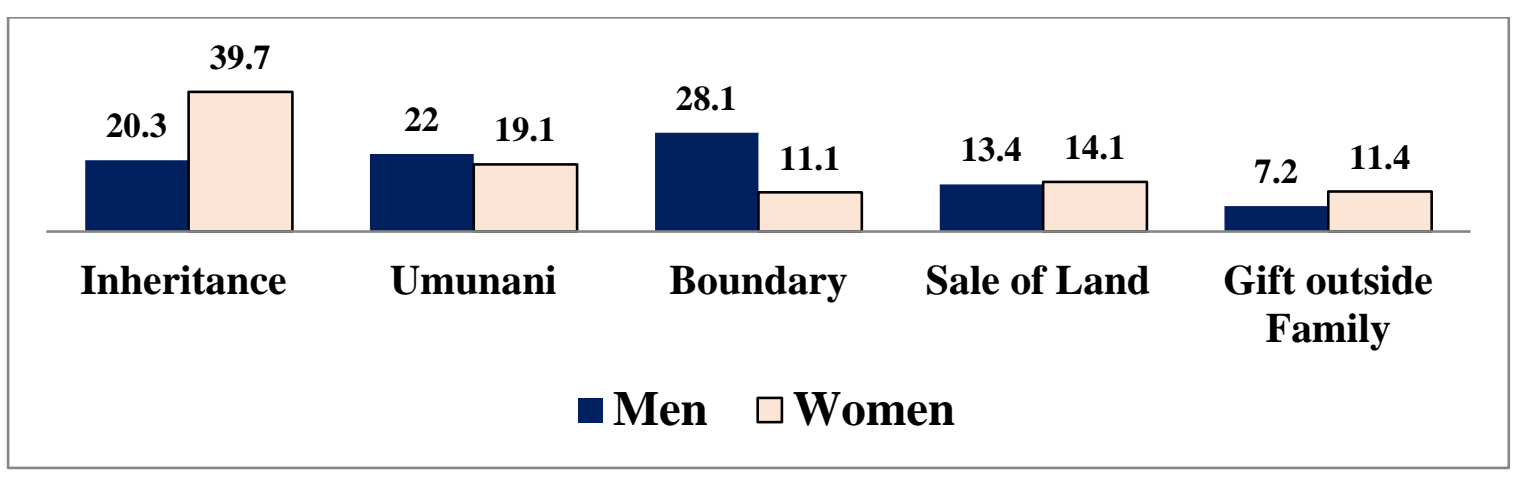

Women went through more disputes resolution services than men (Figure 8). They were nearly twice as likely as men to go to a formal court (32\% compared to $18 \%$ for men) and much more likely to start at a family court ( $44 \%$ compared to $18 \%$ for men). It is also noticeable that around two thirds of disputes were heard by village leaders (68\% of cases brought by women and $61 \%$ by men), reinforcing the importance of training local leaders in the land and inheritance laws as well as the abunzi. 
Figure 82: Dispute-resolution Mechanisms by Gender, \% Going to each Mechanism

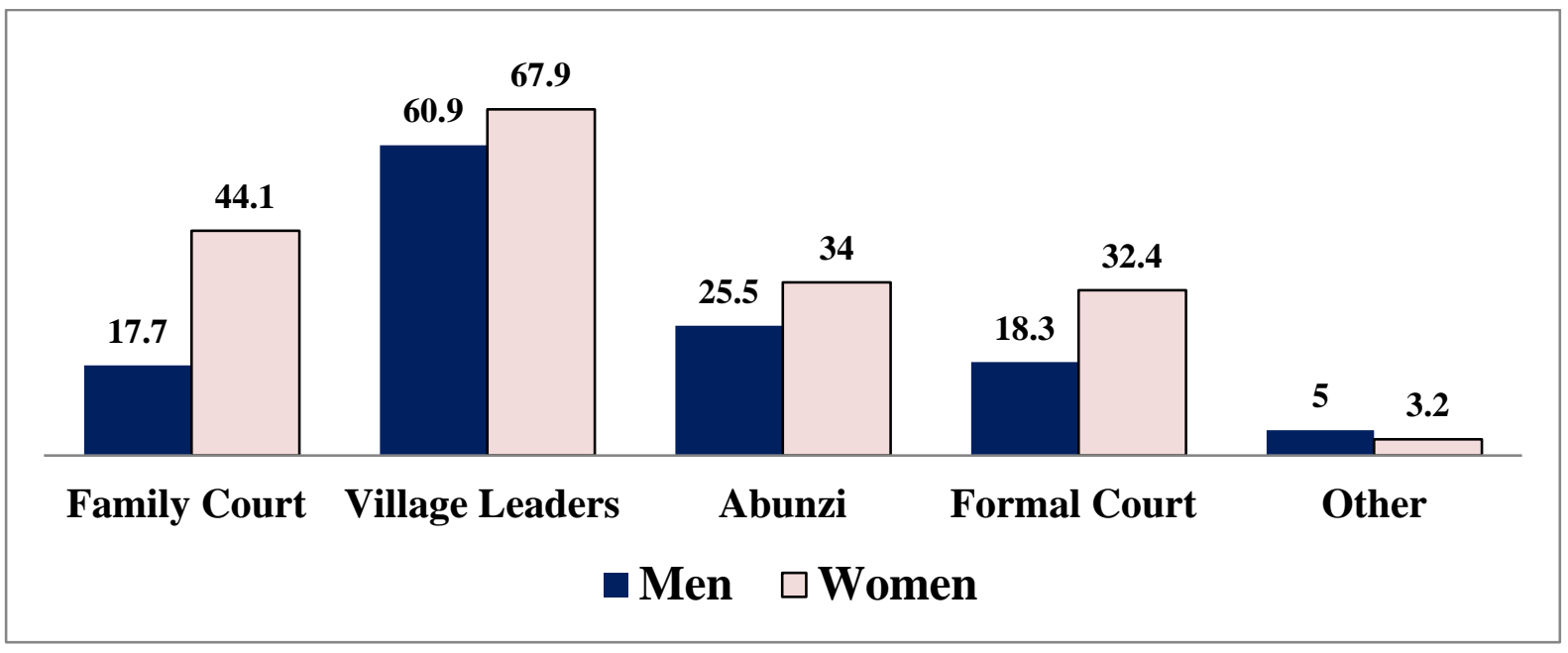

Note: Totals add up to more than $100 \%$ as some disputants use more than one mechanism

Disputes had been resolved to the satisfaction of just over 50\% (50\% men, 55\% women), partly resolved to the satisfaction of $15 \%$ (17\% men, $12 \%$ women) and not yet resolved for $17 \%$ (14\% men, $20 \%$ women). Women were a little more likely to report a satisfactory outcome in all types of location; people who lived in Kigali were less likely, irrespective of gender. A satisfactory report does not, of course, necessarily mean that they obtained what was due them under the law; they many mean merely that they accepted the compromise that was offered.

\section{DISCUSSION}

Previous qualitative research suggests that disputes over land are frequent and place a high burden on informal dispute-resolution mechanisms. An assumption has often been made that most disputes involve women bringing cases against male relatives but there has been no systematic research on a national scale. It was assumed that LTR would reduce the number of disputes because landowners would have titles clearly demarcating the boundary of their land, land would be jointly registered in the names of husbands and wives when they had been formally married under community of property, and all children with a legal interest in the land would be recorded on the land title. Over $90 \%$ of adults think that LTR makes it more likely that land disputes will be resolved and three-quarters that the number of land disputes has declined over the last five years. However, there is little evidence to support the latter belief.

Our survey is the first systematic attempt to investigate the extent to which women and men do understand the laws, using a research sample which is large enough to represent the variety in the wider population and is selected randomly. In the survey only $9 \%$ of women and $13 \%$ of men had any training on their rights, with most relying on community meetings and the media as their main source of information. Three quarters of women and $81 \%$ of men said they thought that they had a basic understanding of their land rights, and in fact our 
findings suggest that over $90 \%$ are aware of women's basic rights to own and inherit land and receive umunami, with little difference between men and women. However, only a fraction are aware of the law in detail - from around three quarters knowing about umunami, through half knowing that registration of marriage and community of property is required for inheritance, to around a third for the inheritance rights of illegitimate children and the distribution of umunami (with men slightly more likely to give the correct answer than women). A much lower proportion have a good working knowledge sufficient to enable them to claim all their legal rights and for informal disputes resolution mechanisms to make decisions in line with the formal law.

The Land Tenure Regulation exercise was designed to ensure that all those who had the right were recorded on the title deeds. Success has not been complete in this respect, but a substantial majority of the women in question have indeed been named on the deeds. The law does not compel registration of women who are married de facto but whose marriage is not registered, but a significant proportion of them also appear on the deeds, and it will be interesting to see how this is handled when inheritance becomes an issue.

Women do appear to have some knowledge of their legal rights, and this is also true of those who will be involved in mediation and the resolution of land disputes, though their knowledge is often patchy. However, women are still not able to claim everything to which the law entitles them; traditional practice and the culturally presupposed ontology which underlies it often inform the decisions that are taken, at the stage of informal conflict resolution. This is not the clash between statute and traditional law which takes place in some countries; in Rwanda there is no traditional law to be upheld in the courts. Traditional practices may legitimately be taken into account transitionally in the absence of a written Law, but laws are proliferating; to some extent the law may codify traditional practice, but often it changes it, as is the case with the land and inheritance laws.

There is still a substantial research literature on legal pluralism in Rwanda, but it is mostly concerned with the time before the Genocide, and Rwanda has reinvented itself in legal terms since the events of 1994. Some of this reinvention may indeed consist in the re-use of traditional governance mechanisms such as Gacaca and the abunzi, but they are reinvented for specific purposes (Nagy 2009, Clark 2010). Gacaca, formerly a local court providing conciliation and restorative solutions to reasonably minor civil and sometimes criminal complaints, was reconstituted for the explicit purpose of dealing expeditiously with the people still in prison as a result of the Genocide - over 130,000 of them, whose investigation and reintegration would have taken longer than the lifespan of the prisoners by conventional means (Tirrell 2015). The abunzi (mediators) were reinvented as a compulsory and mostly affordable stage before going to the expense of bringing issues such as land disputes to the formal courts and to reduce court case-loads. In the early $20^{\text {th }}$ century Rwandan law refers to 'traditional practices' as a basis for decision making where there is no written law, but such remnants are being closed off one by one and replaced by written legislation. In the area of land ownership, the 20005 Law recognises that it is making a change in traditional practice: 'It also institutes the principles that we respect on land legal rights' (Organic Law 18/2005, Article 1 - our emphasis). Custom and tradition as a source of property rights is recognised in 
the 2005 Land Law as a sound reason for issuing a Land Certificate, but Land Tenure Regularisation is precisely about converting this customary basis into a written certificate of leasehold ownership, and while this provision persists transitionally in the 2013 Law which replaced it (given that LTR was not then quite complete), the Law also declares that 'the State is the sole authority to accord rights of occupation and use of land...' (Article 3).

Daily practice between husband and wife is nonetheless not as equitable as the laws would appear to demand. Co-ownership of land does not necessarily mean that women exercise control over it; land is still frequently regarded as 'really' belonging to men (Abbott and Rwica 2014, Mechta et al 2016, Santos et al 2014). The major barrier to gender equality and the implementation of the laws and policies appears to lie in deeply embedded cultural values and practices that continue to construct women as 'naturally' inferior (Batliwala 1994). The barrier in practice to women being able to claim and exercise the rights that Rwandan law and Rwandan policy confer on them follows from the continuing dominance, despite the law, of traditional, customary norms that devalue the work women do (Debusser and Ansoms 2013) and construct women as inferior to men and needing to be controlled by them (Abbott and Malunda 2015).

These norms do not need to be codified in propositional terms; they are visible to both women and men as part of lived experience.

- It is women who are responsible for most of the reproductive work. This may be true across most of the world, but in poor Africa this means more than it would in, say, rich England, because we are talking not only of housework and childcare but also wood and water, whose collection is the work of women, girls and children - you will rarely or never see a boy past puberty in the water queue - and may require hours of work each day.

- Much of the agriculture is also done by women - 'feeding the family' (see Abbott and Malunda 2014) - and this is classed with housework rather than as 'productive' (i.e. paid) work.

- Where jobs are available, men are more likely to get them than women, and it is men more than women who are succeeding in building 'household enterprises' that generate income. Where women do set up such enterprises they are likely to be small in scale and in the informal sector of the economy (IFC 2008, Masinjila 2010). One reasons for this is the social norms - the shared views of what is 'proper' and 'appropriate' for men and (and we make no suggestion that Rwanda is unique in this respect). Behind this again, however, is the fact that women simply do not have the time for outside work; someone has to do the housework and feed the family. Women work on average twenty hours a week longer than men (Strode et al 2007, Abbott et al 2014c).

- Because women do not seek outside work to the same extent as men, their ties to the home become a 'fact' warranted by lived experience. Men's view (shared to some extent by women) that women are different and inferior is reinforced by it and feeds into what we might call 'village governance', whereby a man bears the responsibility for his household's behaviour and is expected to keep it under control.

Sometimes control is necessary, an uncontrolled woman can make mistakes; this control is in order help her to have good conduct and behaviour. 
(Member of an adult male focus group in Kicukiro district of Kigali Abbott et al 2014b)

- In a bizarre form of backlash, women tell us, government 'sensitisation' to women's equality can even add to women's work burden - that now that they 'have equality' they should also be going out and making money as well as doing all the domestic and childcare work and most of the farming (Abbott and Malunda 2015).

Given that it is the men, however, who are mostly finding or making outside work and bringing in the money, it 'stands to reason' that men retain the dominant position in the family discourse and control the spending of it. However, this 'reason' stands as reasonable only within a discourse where women's work carries no such obvious value and is taken for granted as 'just what women do' for the most part (Abbott and Alinda 2012). If a fair value were placed on 'housework' - which, we must remember, includes agricultural labour in Rwanda - then it might often turn out that the man's additional contribution was trivial; not many casual labourers or self-employed 'household enterprises' could feed a family. The same may often be true even where the men's work consists in growing and marketing a cash crop. Thus the set of social processes which leads to women's experience of themselves as incapable and to men's expectation of domestic control rests on beliefs - that men have a duty to keep women under control, that the labour women perform has no monetary value - which are absorbed from a historical discourse of what it is to be a man or a women.

Another point worth making is that people in Rwanda generally think that men should control property and money because it is they who brought them to the marriage. This has generally been true in the past but it may not be so in the future: women can own and inherit land, and increasingly they will bring land to the marriage which was received from their parents at umunami, now that parents may not make larger umunami land gifts to boys than to girls, under the 2016 Law. However, prior ownership of land is only one of many pillars supporting the traditional view that it is men who own the land and have the competence to take decisions about it, and unless/until gender attitudes change land ownership will not necessarily empower women.

Male dominance in the household is beginning to loosen; where women do earn money they do get more say in the family decisions (Abbott et al 2015). Much more is needed if discursive equality is to be reached, however: a recognition of women's work on the land as farming rather than housework, a more equal sharing out of reproductive labour, and ultimately the development of a form of masculinity which is not threatened by women's empowerment. Regrettably there is not as much civil society advocacy of women's rights as would be found in some other countries. Women were very active politically in the early post-Genocide years and made a substantial impact on the content of the 2003 Constitution, but some of the most effective of them became Members of Parliament and were diverted away from specifically women's issues to the governance of Rwanda more generally (Abbott and Malunda 2015). In any case, divisive advocacy by independent institutions is not something the Rwandan political state naturally encourages, and its instrument for expressing its commitment to the emancipation of women has been an official Women's Council to look 
after women's issues. However, the Women's Council is underfunded, and its mere existence tends to 'crowd out' the independent organisations which might have lobbied for change (Abbott et al 2014a).

\section{CONCLUSION}

In conclusion, land ownership is central to life as a Rwandan, and the laws and the process of land tenure regularisation have guaranteed some women their fair share of household land, namely those who are registered as married and are in a marriage where community of property has been chosen. Women in other sorts of union are not protected by the laws, but a significant number have in fact been named as co-owners on their household's land certificates, which might become a loophole through which this injustice could be overcome. Both women and men tend on the whole to have a basic knowledge of the land and inheritance laws, and while far fewer have a good working knowledge sufficient to sustain them through dispute procedures, those who do understand the law quite well are a significant minority. Thus some of the conditions for empowerment are fulfilled: rights have been established, women are aware that they have these rights, they do claim their rights when they are infringed and at least some have sufficient knowledge to be able to bring a successful claim.

However,

- in practice women's co-ownership does not always give them a say in the management of their household's land - there is an overwhelming 'feeling' that land 'really' belongs to men and that men rather than women have the competence to deal with it.

- When it comes to disputes a majority of women cannot afford the cost of formal court proceedings and all are required by law to go through a mediation process first.

- This means that cases are adjudicated by informal 'family courts' and/or by the village leader and elders and/or by the abunzi - many cases go through several of these stages, which wears claimants down, and

- through lack of legal knowledge on the one hand and a mission to procure consensus on the other, decisions are made which again reflect the 'feeling' of men's superior eligibility for land ownership.

What we are talking about is a clash of discourses or cultures or ways of life. One is embodied in 'western-style' law which sees individuals as subject to laws - governance is the Rule of Law - and the law does not discriminate between individuals. 'human rights' are another product of this discourse. The battle is not entirely won even on its home territory; in the countries of the North and West. patriarchy has not disappeared and patriarchal norms still have their appeal, though the discourse that underlies rights and laws is now well known and mostly dominant. What emerges in Rwanda as a barrier to women's empowerment when they are forced to accept compromise solutions in mediation is a different culture or discourse in which it is natural to think of men as in charge and women as incompetent or inferior. The mere fact of being required to go through mediation before taking a dispute to court - and in 
many cases the inability to afford court proceedings - lays claimants open to compromise and receiving less than their legal due in a discourse in which law is not something to be obeyed because it is the law, but something to be obeyed because there is consensus (among competent adults, which often means males). Rwanda's emphasis on 'dialogue and consensus' expresses this second discourse. Overall, women's structural position - the 'normal' demands on their time and energy, together with traditional social rules and societal decision-making practices - reduces the impact of procedures such as LTR and contributes to making women's empowerment hard for a government to achieve.

\section{REFERENCES}

\section{Laws}

Official Gazette of the Republic of Rwanda. 15 ${ }^{\text {th }}$ November 1999 Law $N^{0}-22 / 99$ of 12/11/1999 to Supplement Book One of the Civil Code and to Institute Part Five Regarding Matrimonial Regimes, Liberalities and Successions.

Official Gazette of the Republic of Rwanda. $4^{\text {th }}$ June 2003. Organic Law Special of $4^{\text {th }}$ June 2003 The Constitution of the Republic of Rwanda. Fundamentally amended in 2015 - OG Special of 24/12/20125.)

Official Gazette of the Republic of Rwanda. 15 September 2005. Organic Law N $08 / 2005$ of 14/07/2005 Determining the Use and Management of Land in Rwanda. Kigali: Repealed, replaced by Law No 43/2013 of 16/06/2013 Governing Land in Rwanda.

Official Gazette of the Republic of Rwanda. 14/06/2010. Organic Law No. 24/2010 Organic Law on the organisation, jurisdiction, competence and Functioning of the Mediation Committee. Substantially revised in 2015: OG. 29/2015.

Official Gazette of the Republic of Rwanda. 20/07/2015. Organic Law N0 02/2015 of 16/07/2015 On the Organisation, Jurisdiction, Competence and Functioning of the Mediation Committee.

Official Gazette of the Republic of Rwanda. 08/07/2016. Law N 27/2016 Governing Matrimonial Regimes, Donations and Inheritance.

\section{Other studies cited}

Abbott P. 2015. Land Rights and Land Tenure Regularisation in Rwanda. Paper given at the Gender Centre, University of Rwanda., https://www.researchgate.net/profile/Pamela Abbott3.

Abbott P, Alinda F. 2012. Women's Economic Empowerment and Land in Rwanda. Oxfam: Kigali. 
Abbott P, Kemirembe O, Malunda D. 2014c Mapping of Existing Initiatives on Women in Agriculture in Rwanda. IPAR-Rwanda: Kigali.

Abbott, P, Malunda D (2014) Analysis of Three Rwanda Strategic Agricultural Policies and Programmes (Vision 2020, EDPRS, PSTA) with a Critical Gender-Informed Review of their Implementation and Financing. ActionAid: Kigali.

Abbott P, Malunda D. 2015. The Promise and the Reality: Women's Rights in Rwanda. Working Paper No. 5, Faculty of Law Human Rights Hub, University of Oxford.

Abbott P, Malunda D, Mugisha R, Mutesi L, Rucogoza M. 2012. Women's Economic Empowerment in Rwanda: A Situational Analysis. Ministry of Trade and Industry: Kigali.

Abbott P, Mugisha R. 2015. Land Tenure Regularisation Programme: Progress Report for Selected Indicators. DfID: Kigali. https://www.researchgate.net/profile/Pamela_Abbott3/ publication/283420713_Land_Tenure_Regularisation_in_Rwanda_Progress_Report_for_S elected_Indicators/links/5637977408ae1740c93b1c2a/Land-Tenure-Regularisation-inRwanda-Progress-Report-for-Selected-Indicators.pdf

Abbott P, Mugisha R, Lodge G. 2014a. The Constant Quest for Solutions through Dialogue and Consensus. Republic of Rwanda, Kigali.

Abbott P, Mutesi L, Norris E. 2015. Gender Analysis for Sustainable Livelihoods and Participatory Governance in Rwanda. Oxfam: Kigali.

Abbott P, Rwica J. 2014. End-of-Line Evaluation of 'Beyond Raising Awareness: Shifting the Power Balance to Enable Women to Access Land in Rwanda'. RCN J\&D: Kigali

Abbott P, Rwirahira J, Mugisha R, Mutesi L, Tuyishime C, Vuningoma L. 2014b. Lifestyle and Sexual and Reproductive Health in Rwanda: Findings from a Purposive Qualitative Study. Kigali: IPAR-Rwanda: Kigali.

Abbott P, Sapsford R. 2016. Precarious developmental success: social reconstruction in Rwanda. Paper presented at an international Workshop in Bonn on Rwanda: A

Developmental State and/or Donor Darling? German Development Institute, Radboud University: Bonn.

Batliwala S. 1995 Defining Women's Empowerment: A Conceptual Framework. In Batliwala S. (ed.), Education for Women's Empowerment, ASPBAE Position Paper for the Fourth World Conference on Women. Beijing, September. Asia-South Pacific Bureau of Adult Education: Delhi.

Bayisenge J, Hojer S, Espling M. 2015. Women's Land Rights in the context of the Land Tenure Reform in Rwanda -The Experiences of Policy Implementation. Journal of Eastern African Studies 9: 74-90.

Booth D, Golooba-Mutebi F. 2011. Developmental Patrimonialism? The Case of Rwanda. Overseas Development Institute: London.

Burgess P. 2007. Women Empowered: Inspiring Change in the Emerging World. Rizzoli: New York.

Burnet J. 2011. Women have Found Respect: Gender Quotas, Symbolic Representation, and Female Empowerment in Rwanda. Politics and Gender 7: 303-344. 
Clark, P. 2010. The Gacaca Courts, Post-Genocide Justice and Reconciliation in Rwanda: justice without lawyers. Cambridge: Cambridge Unbiversity Press.

Collier P. 2010. Wars, Guns and Votes: Democracy in Dangerous Places. Vintage Books: London.

Debusser P, Ansoms A. 2013. Gender Equality Politics in Rwanda: Public Relations or Role Transformation. Development and Change 44: 1111-1134

Elborgh-Woytek K, Newiak M, Kochhar, K, Fabrizio S, Kpodar K, Wingender P, Clements B, Schwartz G. 2013. Women, Work, and the Economy: Macroeconomic Gains from Gender Equity. Staff Discussion Paper, International Monetary Fund: Washington DC.

IFC - International Finance Corporation. 2008. Voices of Women Entrepreneurs in Rwanda. World Bank: Washington DC.

Masinjila M. 2010. Gender Dimensions of Cross Border Trade in the East African Community - Kenya/Uganda and Rwanda/Burundi Border. United Nations Economic Commission for Africa: Addis Ababa.

Mechta S, Buscagli ., Bikesha D, Routte J. 2016. Decision-Making and Joint Control Rights over Land in Rwanda. International Alert: London.

Ministry of Finance and Economic Planning. 2014. Macro-framework Public Data Set. Kigali: Republic of Rwanda. http://www.minecofin.gov.rw/index.php?id=173

Mutisi M. 2012. Local Conflict Resolution in Rwanda: The Case of Abunzi Mediators. In Mutisi, M,. Sansculotte-Greenridge K (eds.) Integrating Traditional and Modern Conflict Resolution: Experiences from Selected Cases in Eastern and the Horn of Africa. African Dialogue Monograph Series No 2, African Centre for the Constructive Resolution of Disputes. http://www.isn.ethz.ch/Digital-Library/Publications/ Detail/?id=146648.

Nagy R. 2009. Legal pluralism in transitional context: the case of Rwanda's Gacaca courts. In Quinn, J. (ed) Reconciliation(s): transitional justice in postconflict societies. Montréal: McGill-Queen's University Press.

NISR- National Institute of Statistics of Rwanda. 2012a EICV3 Main Report. Republic of Rwanda: Kigali. http://www.new-ag.info/en/focus/focusItem.php?a=2930

NISR. 2012b. EICV3 Thematic Report: Economic Activity Republic of Rwanda: Kigali.

NISR. 2012c. EICV3 Thematic Report: Environment and Natural Resources. Republic of Rwanda: Kigali.

NISR. 2015a. Rwanda Integrated Household Living Conditions Survey [EICV] 2013-14: Main Indicators Report. Republic of Rwanda: Kigali.

NISR. 2015b. Seasonal Agricultural Survey 2014. Republic of Rwanda: Kigali.

Niyonsaba I, Bisiaux R, Habimana D. 2013. LTR Log Frame Target Quantitative and Qualitative Surveys: Final Report. Coffey International Development: Reading. 
Randell S, McCloskey M. 2014. Sustainable Rural Development in Rwanda: The Importance of the Focus on Agriculture. International Journal of Agricultural Extension for Sustainable Development: 107-119.

Rwanda Women's Network. 2011. The Experiences of Women in Asserting their Land Rights: The Case of Bugesera District. Rwanda Women's Network: Kigali.

Santos F, Fletschner D, Daconto G. 2012. Enhancing inclusiveness of Rwanda's land tenure regularisation programme: initial impacts of an awareness-raising pilot. Paper prepared for the Annual World Bank Conference on Land and Poverty.

Santos F, Fletschner D, Savath, V. 2014. An Intra-Household Analysis of Access to and Control over Land in the Northern Province, Rwanda. Paper prepared for the Annual World Bank Conference on Land and Poverty.

Strode M, Wylde E, Murangwa Y. 2007. Labour Market and Economic Activity Trends in Rwanda. NISR: Kigali.

Tirrill, L. 2015. Traditional justice in post-Genocide Rwanda: an integrative approach. In: Corrandetti C, Eiskovits $\mathrm{N}$ and Rotondi J. (eds) Theorising Transitional Justice. Aldershot: Ashgate.

UNHabitat, IFAD, GLTN. 2012. Land and Natural Resources Tenure Security Learning Initiative for East and Southern Africa: Rwanda Country Report. UNHabital: Nairobi.

United Nations. 1979. Convention on the Elimination of All Forms of Discrimination against Women. http://www.un.org/womenwatch/daw/cedaw.htm

USAID Land Project. 2014a. The Gendered Nature of Land and Property Rights in PostReform Rwanda: Policy Research Brief. USAID Land Project: Kigali.

USAID Land Project. 2014b. Assessment of Citizen Vulnerability and Knowledge of LandRelated Law in Rwanda: Research Policy Brief. USAID Land Project: Kigali.

Uwayezu E, Mugiraneza T. 2011. Land Policy Reform in Rwanda and Land Tenure Security for all Citizens: Provision and Recognition of Women's Rights over Land. FIG Working Week 2011, Paper No 4914: Marrakech.

Veldman M, Lankhorst M. 2011. Legal Empowerment and Customary Law in Rwanda: Report on a Pilot Project Concerning Community Level Dispute Resolution and Women. Rome: International Development Law Organisation.

World Bank. 2012. 2012 World Bank Development Report: Gender Equality as Smart Economics. The World Bank: Washington DC.

\section{Endnote}

Rwandan inheritance law has changed again since this research was carried out, and some of the detail is different, but the principles which it expresses remains the same. Law No 27/2016 Governing Matrimonial Regimes, Donations and Inheritance contains the following main changes: 
1. Parents are still not required to make umunami donations of land to their children, but if they do so they must treat sons and daughters equally (articles 27 and 28)

2. Only legitimate children automatically succeed (article 54). However, illegitimate children inherit from their mother (article 73), being recognised by her automatically, and any child has a right to inherit if formally recognised by the father (article 76), as in the preceding law.

3. For the first time, the surviving spouse has the same right to inherit from the husband as the other heirs (article 75). (The Law does not actually say that the 'spouse' has to be formally married and registered, but we presume that this is still the case.) Under community of property the surviving spouse inherits all the property, with a duty to look after the children (article 76). However, if the surviving spouse remarries then he or she keeps half the property (as would happen in any case) and shares the other half with the children, if any. 
